\title{
Sr-90 Deposition Observed in Central and Northeast Honshu Island, Japan, after the Fukushima Dai-ichi Nuclear Power Plant Accident Katsumi Hirose
}

Department of Materials and Life Sciences, Faculty of Science and Technology, Sophia University, 7-1 Kioicho, Chiyodaku, Tokyo 102-8554, Japan

\begin{abstract}
Monthly depositions of anthropogenic radionuclides, which directly reflect atmospheric processes including emission from the Fukushima Dai-ichi Nuclear Power Plant (FDNPP), are an important probe to re-construct FDNPP accident sequence. Japanese radioactivity survey network monitored monthly ${ }^{90} \mathrm{Sr}$ deposition after the FDNPP accident. The highest monthly ${ }^{90} \mathrm{Sr}$ deposition $\left(470 \pm 17 \mathrm{~Bq} \mathrm{~m}^{-2}\right)$ was observed in March 2011 at Futaba near the FDNPP site, which is the same order of magnitude as that due to global fallout observed in 1963. The higher ${ }^{90} \mathrm{Sr}$ deposition in March 2011 occurred in the Kanto and inland of the Tohoku areas. The monthly ${ }^{90} \mathrm{Sr}$ deposition decreased with time, as $\mathrm{did}^{137} \mathrm{Cs}$. Atmospheric effect of the FDNPP-derived ${ }^{90} \mathrm{Sr}$ continued more than 1 year. ${ }^{90} \mathrm{Sr} /{ }^{137} \mathrm{Cs}$ activity ratios in March 2011, which were in the range from $0.99 \times 10^{-4}$ to $3 \times 10^{-4}$, showed no large spatial variation. This result allowed us to estimate total atmospheric emission of ${ }^{90} \mathrm{Sr}$ from the FDNPP accident from the total atmospheric release of ${ }^{137} \mathrm{Cs}$. The total release amount of ${ }^{90} \mathrm{Sr}$ at an early stage of accident was calculated to be $2.7-$ 3.6TBq.
\end{abstract}

Publication History:

Received: March 20, 2017

Accepted: July 20, 2017

Published: July 22, 2017

\section{Keywords:}

Fukushima, ${ }^{90} \mathrm{Sr}$, Deposition, Temporal variation, Radioactivity emission

\section{Introduction}

On 11 March 2011, the Richter scale 9.0 magnitude earthquake, so called "the 2011 Great East Japan Earthquake", and Tsunami struck the northeast coast of Japan, resulting in widespread injury and loss of life. These natural disasters caused severe accident in the Fukushima Dai-ichi Nuclear Power Plant (FDNPP) [1]. As a result, large amounts of radionuclides have been released in the environment $[1,2]$. Japanese government, research institute and university have continuously monitored the FDNPP-derived radionuclides in the atmospheric samples [3-8]. Just after the FDNPP accident, ${ }^{131} \mathrm{I},{ }^{134} \mathrm{Cs}$ and ${ }^{137} \mathrm{Cs}$ were detected as dominant FDNPP-derived radionuclides in atmospheric samples such as atmospheric dust and deposition, whereas refractory radionuclides such as ${ }^{103} \mathrm{Ru}$ and ${ }^{95} \mathrm{Zr}$ could not be detected [3-5]. In contrast to volatile radionuclides such as radiocesium, there is only limited information on atmospheric behaviors of FDNPP-derived radiostrontium ${ }^{89} \mathrm{Sr}$ (half life: $50.53 \mathrm{~d}$ ) and ${ }^{90} \mathrm{Sr}$ (half life: 28.79 y) $[8]$ because radiostrontium was a minor release component due to un-volatile properties of oxide [9]. Total atmospheric emissions of ${ }^{89} \mathrm{Sr}$ and ${ }^{90} \mathrm{Sr}$ from the FDNPP accident were estimated to be about one and two orders of magnitude lower than ${ }^{137} \mathrm{Cs}$, respectively[1]. Although radiostrontium is a minor component within the FDNPP-derived radionuclides, knowledge on radiostrontium derived from the FDNPP is important to have better understanding of characteristics of the FDNPP accident.

The monthly ${ }^{90} \mathrm{Sr}$ deposition have been monitored by Japanese Radioactivity Survey project since the late 1950s, in which major part has been performed by Meteorological Research Institute (MRI) [1013]. After the FDNPP accident, the monthly ${ }^{90} \mathrm{Sr}$ deposition observed at Tsukuba was reported [8], in which the monthly ${ }^{90} \mathrm{Sr}$ deposition in March 2011 increased to $5.2 \pm 0.1 \mathrm{~Bq} \mathrm{~m}^{-2}$, being more two orders magnitude greater than that in the late 2000s. However, there is no report about atmospheric dispersion of the FDNPP-derived ${ }^{90} \mathrm{Sr}$ in Japan.

Activity ratios of ${ }^{89} \mathrm{Sr}$ and ${ }^{90} \mathrm{Sr}$ are an important indicator to identify freshly released ${ }^{90} \mathrm{Sr}$ using ${ }^{89} \mathrm{Sr}$ with a short half-life. Although after the FDNPP accident ${ }^{89} \mathrm{Sr}$ was detected in airborne dust $\left({ }^{89} \mathrm{Sr} /{ }^{90} \mathrm{Sr}\right.$ : 15) [8] and seawater $\left({ }^{89} \mathrm{Sr} /{ }^{90} \mathrm{Sr}\right.$ : $\left.11.8 \pm 0.8\right)$ [14], there is very limited information on ${ }^{89} \mathrm{Sr}$ in environmental samples because of complicated and time-consuming radiochemical procedure. Activity ratios of ${ }^{90} \mathrm{Sr}$ to ${ }^{137} \mathrm{Cs}$ are a useful tool to identify sources of radioactive releases and to have better understanding of environmental behaviors of these radionuclides $[15,16]$. The annual mean ${ }^{90} \mathrm{Sr} /{ }^{137} \mathrm{Cs}$ activity ratios of deposition samples in the period of 1980 to 1985 were a range from 0.43 to 0.77 , which is due to radioactive fallout from the $26^{\text {th }}$ Chinese atmospheric nuclear test conducted in October 1980 [17]. In May 1986 just after the Chernobyl accident, the ${ }^{90} \mathrm{Sr} /{ }^{137} \mathrm{Cs}$ ratio in a Tsukuba deposition sample decreased to 0.0094 . The ${ }^{90} \mathrm{Sr} /{ }^{137} \mathrm{Cs}$ ratios in deposition samples varied in the 1990s and 2000s due to effects of resuspension and terrestrial processes [13,18,19]. In March 2011 just after the FDNPP accident, the marked low ${ }^{90} \mathrm{Sr} /{ }^{137} \mathrm{Cs}$ ratio (about $2 \times 10^{-}$ $\left.{ }^{5}\right)$ was observed in the deposition sample collected at Tsukuba [8]. To have better understanding of environmental behaviors of the FDNPPderived radionuclides and the FDNPP accident sequence, therefore, it is important to examine the spatial and temporal variations of the ${ }^{90} \mathrm{Sr} /{ }^{137} \mathrm{Cs}$ ratios in deposition samples.

In this paper, we describe spatial distributions and temporal variationsof the monthly ${ }^{90} \mathrm{Sr}$ deposition observed in the central and eastern Honshu Island, Japan, after the FDNPP accident, and discuss total atmospheric emission of ${ }^{90} \mathrm{Sr}$ from the FDNPP.

\section{Sampling and Method}

Monthly ${ }^{90} \mathrm{Sr}$ deposition data recorded in Environmental Radioactivity database[20] were used for analysis of its temporal variation. Monthly radioactivity deposition samples have been collected at radioactivity monitoring stations by Meteorological ${ }^{*}$ Corresponding Author: Dr. Katsumi Hirose, Department of Materials and Life Sciences, Faculty of Science and Technology, Sophia University, 7-1 Kioicho, Chiyodaku, Tokyo 102-8554, Japan; E-mail: hirose45037@mail2.accsnet.ne.jp

Citation: Hirose K (2017) Sr-90 Deposition Observed in Central and Northeast Honshu Island, Japan, after the Fukushima Dai-ichi Nuclear Power Plant Accident. Int J Earth Environ Sci 2: 134. doi: https://doi.org/10.15344/2456$351 \times / 2017 / 134$

Copyright: (c) 2017 Hirose. This is an open-access article distributed under the terms of the Creative Commons Attribution License, which permits unrestricted use, distribution, and reproduction in any medium, provided the original author and source are credited. 
Citation: Hirose K (2017) Sr-90 Deposition Observed in Central and Northeast Honshu Island, Japan, after the Fukushima Dai-ichi Nuclear Power Plant Accident. Int J Earth Environ Sci 2: 134. doi: https://doi.org/10.15344/2456-351X/2017/134

Page 2 of 5

Research Institute (MRI, Tsukuba) and local government laboratories. The monitoring stations in central and eastern regions in Japan (latitudinal range: $35^{\circ} \mathrm{N}-40^{\circ} \mathrm{N}$, longitudinal range: $138^{\circ} \mathrm{E}$ $-141^{\circ} \mathrm{E}$, Figure 1) are as follows; Akita $\left(39.72^{\circ} \mathrm{N}, 140.13^{\circ} \mathrm{E}\right)$, Morioka $\left(39.68^{\circ} \mathrm{N}, 141.13^{\circ} \mathrm{E}\right)$, Yamagata $\left(38.25^{\circ} \mathrm{N}, 140.33^{\circ} \mathrm{E}\right)$, Futaba $\left(37.40^{\circ} \mathrm{N}\right.$, $\left.140.99^{\circ} \mathrm{E}\right)$, Utsunomiya $\left(36.60^{\circ} \mathrm{N}, 139.94^{\circ} \mathrm{E}\right)$, Hitachinaka $\left(36.39^{\circ} \mathrm{N}\right.$, $\left.140.43^{\circ} \mathrm{E}\right)$, Maehashi $\left(36.40^{\circ} \mathrm{N}, 139.10^{\circ} \mathrm{E}\right)$, Tsukuba $\left(36.1^{\circ} \mathrm{N}, 140.1^{\circ} \mathrm{E}\right)$, Tokyo $\left(35.71^{\circ} \mathrm{N}, 139.70^{\circ} \mathrm{E}\right)$, Ichihara $\left(35.53^{\circ} \mathrm{N}, 140.07^{\circ} \mathrm{E}\right)$, Chigasaki $\left(35.33^{\circ} \mathrm{N}, 139.38^{\circ} \mathrm{E}\right)$, Shizuoka $\left(35.00^{\circ} \mathrm{N}, 138.39^{\circ} \mathrm{E}\right)$, Kofu $\left(35.67^{\circ} \mathrm{N}\right.$, $\left.138.55^{\circ} \mathrm{E}\right)$, Nagano $\left(36.64^{\circ} \mathrm{N}, 138.18^{\circ} \mathrm{E}\right)$, Niigata $\left(37.85^{\circ} \mathrm{N}, 138.94^{\circ} \mathrm{E}\right)$, and Toyama $\left(36.70^{\circ} \mathrm{N}, 137.10^{\circ} \mathrm{E}\right)$. Monthly deposition samples (rainwater and falling dust) were collected by rainwater samplers with surface areas of $0.5 \mathrm{~m}^{2}\left(4 \mathrm{~m}^{2}\right.$ for MRI), which are usually installed on the roof of main monitoring building in each monitoring station. Monthly rainwater and falling dust samples was collected in appropriate bottles on the first day morning of every month.

We briefly describe the method of sample preparation and ${ }^{90} \mathrm{Sr}$ measurements in detail described elsewhere [21]. ${ }^{90} \mathrm{Sr}$ analysis has been performed by MRI and Japan Chemical Analysis Center (JCAC). Water sample was dried on a hot plate. The resultant residues were weighted after drying in an oven at $110^{\circ} \mathrm{C}$ and then transferred to a plastic container. Dried residue sample in a plastic container was subjected by gamma spectrometry. After the gamma survey, the deposition samples collected by local government laboratories were transported to JCAC. A part of the deposition sample was subjected to ${ }^{90} \mathrm{Sr}$ measurements. The deposition samples were decomposed with conc. $\mathrm{HNO}_{3}$ and $\mathrm{H}_{2} \mathrm{O}_{2}$, and dissolved in $\mathrm{HNO}_{3}$ solution. To separate $\mathrm{Sr}$ fraction from other natural and anthropogenic beta-emitters, carbonate, oxalate, chromate and iron hydroxide precipitation techniques were performed successively, and the Sr fraction was finally purified by fumic $\mathrm{HNO}_{3}$ technique or ion exchange technique basically according to MEXT manual [21,22]. After that, Sr was precipitated as carbonate and fixed on a $5 \mathrm{C}$ filter paper, which was subjected to beta counting. After the activity measurement sources were left for several weeks to achieve ${ }^{90} \mathrm{Sr}^{-90} \mathrm{Y}$ radioequilibrium, their beta-activities were measured using a low-background $2 \pi$ gas-flow counter (Tennelec LB5100) and determined with a calibration curve, which was made from a relationship between known amounts of ${ }^{90} \mathrm{Sr}$ activity and $\mathrm{SrCO}_{3}$. Counting efficiency $\left({ }^{90} \mathrm{Sr}-{ }^{90} \mathrm{Y}\right)$ was in a range of 50 to $70 \%$. Chemical yield was determined from recovery of added stable Sr. In this case, treatment to remove contribution of ${ }^{89} \mathrm{Sr}$ has been carried out [8]. The ${ }^{90} \mathrm{Sr}$ activity was decay-corrected at mid-sampling. The detection limits of ${ }^{90} \mathrm{Sr}$ were approximately $3.5 \mathrm{mBq} \mathrm{m}^{-2}$ (MRI) and approximately $50 \mathrm{mBq} \mathrm{m}^{-2}$ (JCAC), respectively.

\section{Results and Discussion}

The spatial distributions of monthly ${ }^{90} \mathrm{Sr}$ deposition in March 2011 are depicted in Figure 1A. The monthly ${ }^{90} \mathrm{Sr}$ depositions in the sites within $300 \mathrm{~km}$ apart from the FDNPP, which were in the range from $0.89 \pm 0.023 \mathrm{~Bq} \mathrm{~m}^{-2}$ to $470 \pm 17 \mathrm{~Bq} \mathrm{~m}^{-2}$, are more than one order of magnitude greater than pre-FDNPP accident level $[8,13,23]$. On the other hand, in contrast of ${ }^{137} \mathrm{Cs}[5],{ }^{90} \mathrm{Sr}$ activities in some locations of Kofu $\left(35.65^{\circ} \mathrm{N}, 138.57^{\circ} \mathrm{E}\right.$; inland site) and the Japan Sea side sites (Niigata: $37.91^{\circ} \mathrm{E}, 139.04^{\circ} \mathrm{N}$ and Akita: $39.72^{\circ} \mathrm{E}, 140.10^{\circ} \mathrm{N}$ ) were less than the detection limit. The highest monthly ${ }^{90} \mathrm{Sr}$ deposition was observed at Futaba about $5 \mathrm{~km}$ from the FDNPP, which is higher than the maximum monthly ${ }^{90} \mathrm{Sr}$ deposition $\left(170 \mathrm{~Bq} \mathrm{~m}^{-2}\right)$ originating from the 1961-1962 large-scale atmospheric nuclear testing observed at Koenji (Tokyo) in 1963 [10-12]. The relatively high ${ }^{90} \mathrm{Sr}$ depositions occurred at Hitachinaka and Tsukuba, corresponding to one of major
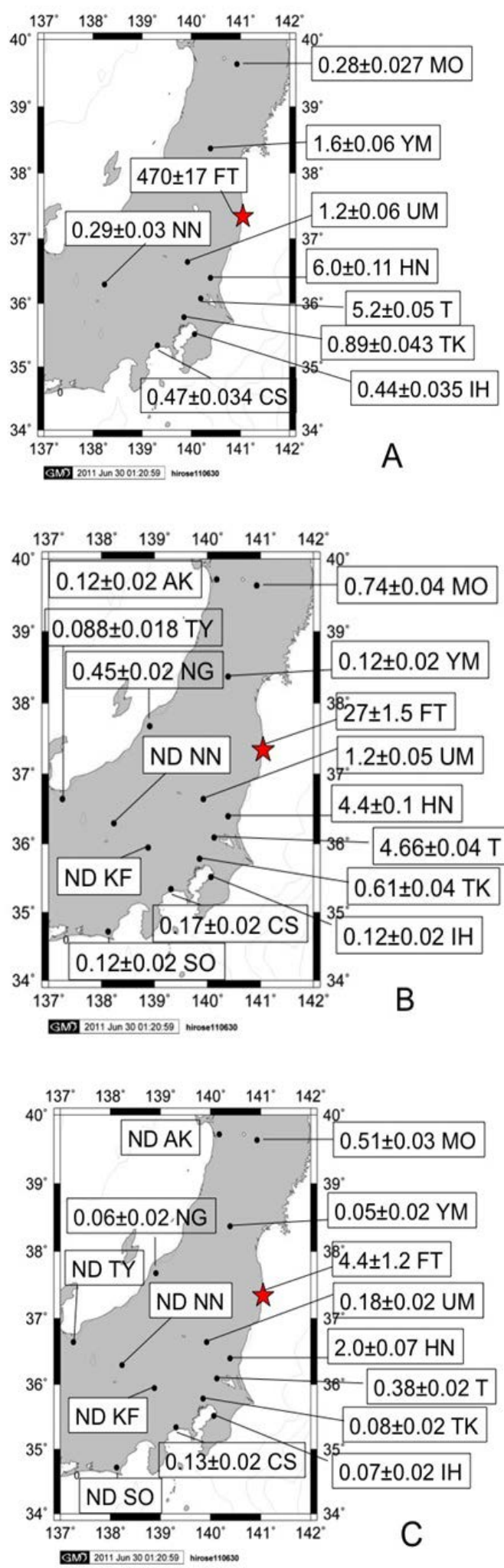

Figure 1: Spatial distributions of monthly ${ }^{90} \mathrm{Sr}$ deposition observed in Japan. (Unit: Bq m²) A: March, B: April, C: May. Abbreviations of station names are shown in Table 1. 
Citation: Hirose K (2017) Sr-90 Deposition Observed in Central and Northeast Honshu Island, Japan, after the Fukushima Dai-ichi Nuclear Power Plant Accident. Int J Earth Environ Sci 2: 134. doi: https://doi.org/10.15344/2456-351X/2017/134

Page 3 of 5

pathway of the radioactive plume derived from the FDNPP accident [24]. The spatial distribution of the ${ }^{90} \mathrm{Sr}$ deposition in March 2011 roughly corresponded to high ${ }^{137} \mathrm{Cs}$ deposition area depicted by aerial monitoring [1]. These findings suggest that ${ }^{90} \mathrm{Sr}$ detected in the deposition samples collected in March 2011 is derived from the atmospheric emission due to the FDNPP accident, which is supported detection of ${ }^{89} \mathrm{Sr}$ (half life: $50.53 \mathrm{~d}$ ) in aerosol samples [8]. In April 2011 as shown in Figure 1B, a region detected ${ }^{90} \mathrm{Sr}$ in deposition samples spread to coastal zone of the central Honshu-Island and coastal sites in the Japan Sea, although the monthly ${ }^{90} \mathrm{Sr}$ depositions in the sites detected in March 2011 decreased. The temporal change of the affected area, where the FDNPP-derived ${ }^{90} \mathrm{Sr}$ was observed, is similar to that of ${ }^{137} \mathrm{Cs}$ [5]. In May 2011 (Figure 1C), the monthly ${ }^{90} \mathrm{Sr}$ deposition in all sites decreased. The spatial distribution of the ${ }^{90} \mathrm{Sr}$ deposition suggests that the atmospheric deposition of the FDNPP-derived ${ }^{90} \mathrm{Sr}$ cannot result in marked enhance of ${ }^{90} \mathrm{Sr}$ deposition density in land surface except area adjacent to the FDNPP. Measurements of ${ }^{90} \mathrm{Sr}$ in soil revealed that a small increase of ${ }^{90} \mathrm{Sr}$ was observed in the exclusion zone near the FDNPP, in which an average ${ }^{90} \mathrm{Sr}$ concentration in surface soil was $17.5 \mathrm{~Bq} \mathrm{~kg}^{-1}$ with a range from 1.4 to $80.8 \mathrm{~Bq} \mathrm{~kg}^{-1}$ whereas out of the exclusion zone there was no significant increase of soil ${ }^{90} \mathrm{Sr}$ having an average ${ }^{90} \mathrm{Sr}$ of $4.6 \mathrm{~Bq} \mathrm{~kg}^{-1}$ with a range from 1.6 to $20.6 \mathrm{~Bq} \mathrm{~kg}^{-1}$, which is the same level as that in the pre-FDNPP era $[25,26]$.

In order to elucidate depositional behaviors of the Fukushimaderived radionuclides, it is important to examine the temporal change of the monthly ${ }^{90} \mathrm{Sr}$ deposition. Temporal variations of the monthly ${ }^{9} \mathrm{Sr}$ depositions during the period from March 2011 to March 2012 are shown in Figure 2. The monthly ${ }^{137} \mathrm{Cs}$ deposition except Morioka exhibited decrease tendency during the period of March to May. We calculated apparent atmospheric half-lives (AAHL) of the Fukushimaderived ${ }^{90} \mathrm{Sr}$ (Table 1). The AAHLs at Futaba and Yamagata are similar to that of the FDNPP-derived ${ }^{137} \mathrm{Cs}$ during the corresponding period [5], whereas the AAHLs in the Kanto plain (19-44 days) are longer than that of the FDNPP-derived ${ }^{137} \mathrm{Cs}$. This finding suggests that the atmospheric behavior and/or emission processes of the FDNPPderived ${ }^{90} \mathrm{Sr}$ were different from ${ }^{137} \mathrm{Cs}$. After June 2011, the level of the monthly ${ }^{90} \mathrm{Sr}$ deposition except several sites decreased to less than detection limit. However, the monthly ${ }^{90} \mathrm{Sr}$ deposition at Futaba near the FDNPP with a range of 0.27 to $2.2 \mathrm{~Bq} \mathrm{~m}^{-2}$ showed no decrease until March 2012. The monthly ${ }^{90} \mathrm{Sr}$ deposition at Hitachinaka about $100 \mathrm{~km}$ south the FDNPP were measureable until November 2011, although ${ }^{90} \mathrm{Sr}$ was detected in several samples collected in 2012. For Tsukuba, the monthly ${ }^{90} \mathrm{Sr}$ deposition decreased until July 2011 and was kept at a constant level $\left(0.01\right.$ to $\left.0.077 \mathrm{~Bq} \mathrm{~m}^{-2}\right)$, which is about one order of magnitude larger than the pre-FDNPP level (2009-2010: ND to $0.0077 \mathrm{~Bq} \mathrm{~m}^{-2}$ ). These findings suggest that the FDNPP-derived ${ }^{90} \mathrm{Sr}$ at least affected in atmosphere of the Kanto plain until early 2012, although its radiological contribution was very small.

${ }^{90} \mathrm{Sr} /{ }^{137} \mathrm{Cs}$ activity ratios in deposition samples are an effective tool to have better understanding of emission and resuspension processes of the FDNPP-derived radionuclides[13,18,19]. We examine the spatial distribution of the ${ }^{90} \mathrm{Sr} /{ }^{137} \mathrm{Cs}$ ratios in the deposition samples collected in Mach 2011. The result is shown in Figure 3. The ${ }^{90} \mathrm{Sr} /{ }^{137} \mathrm{Cs}$ ratios, which ranged from $0.88 \times 10^{-4}$ to $3.5 \times 10^{-4}$ with a median of $1.8 \times 10^{-4}$ , are approximately constant spatially. These ratios are similar with the ${ }^{90} \mathrm{Sr} /{ }^{137} \mathrm{Cs}$ ratios in soil of the exclusion zone with a range from $0.57 \times$ $10^{-4}$ to $3.0 \times 10^{-4}$, although ${ }^{90} \mathrm{Sr}$ in soil contained contribution of ${ }^{90} \mathrm{Sr}$ derived from global fallout $[25,27]$. The median of

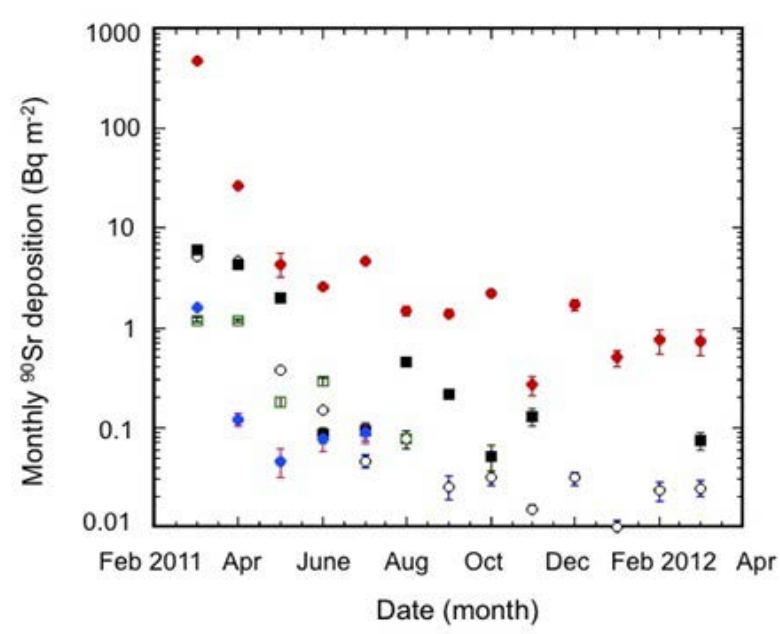

Figure 2: Temporal variations of monthly ${ }^{90} \mathrm{Sr}$ deposition during the period from March 2011 to March 2012. Closed red circle: Futaba, closed black square: Hitachinaka, open black circle: Tsukuba, open green square: Utsunomiya, closed blue circle: Yamagata

\begin{tabular}{|c|c|c|}
\hline Station name & Location & AAHL (days) \\
\hline MO & $39.68^{\circ} \mathrm{N}, 141.13^{\circ} \mathrm{E}$ & $27 \pm 19^{*}$ \\
\hline $\mathrm{YM}$ & $38.25^{\circ} \mathrm{N}, 140.33^{\circ} \mathrm{E}$ & $11 \pm 2$ \\
\hline $\mathrm{FB}$ & $37.40^{\circ} \mathrm{N}, 140.99^{\circ} \mathrm{E}$ & $11 \pm 3$ \\
\hline $\mathrm{HN}$ & $36.39^{\circ} \mathrm{N}, 140.43^{\circ} \mathrm{E}$ & $44 \pm 16$ \\
\hline $\mathrm{UM}$ & $36.60^{\circ} \mathrm{N}, 139.94^{\circ} \mathrm{E}$ & $42 \pm 21$ \\
\hline $\mathrm{T}$ & $36.10^{\circ} \mathrm{N}, 140.10^{\circ} \mathrm{E}$ & $36 \pm 20$ \\
\hline $\mathrm{MH}$ & $36.40^{\circ} \mathrm{N}, 139.10^{\circ} \mathrm{E}$ & $19 \pm 1$ \\
\hline $\mathrm{TK}$ & $35.71^{\circ} \mathrm{N}, 139.70^{\circ} \mathrm{E}$ & $30 \pm 11$ \\
\hline $\mathrm{IK}$ & $35.53^{\circ} \mathrm{N}, 140.07^{\circ} \mathrm{E}$ & $18 \pm 3$ \\
\hline $\mathrm{CS}$ & $35.33^{\circ} \mathrm{N}, 139.38 \mathrm{vE}$ & $26 \pm 6$ \\
\hline
\end{tabular}

Table 1: Apparent atmospheric half-lives of FDNPP-derived ${ }^{90} \mathrm{Sr}$ during the period of March 2011 to May 2011.

${ }^{*}$ AAHL was calculated in the period of April to July because $90 \mathrm{Sr}$ maximum was observed in April 2011.

Abbreviations: AAHL: Apparent Atmospheric Half Life, Monitoring stations, AK: Akita, MO: Morioka, YM: Yamagata, FB: Futaba, UM: Utsunomiya, HN: Hitachinaka, T: Tsukuba, TK: Tokyo, IK: Ichihara, CS: Chigasaki, SO: Shizuoka, KF: Kofu, NN: Nagano, NG: Niigata, TY: Toyama, MH: Maehashi.

the ${ }^{90} \mathrm{Sr} /{ }^{137} \mathrm{Cs}$ ratio in the deposition samples reflects that in the major radioactive emission into atmosphere just after the FDNPP accident. This finding allows us to estimate the atmospheric total ${ }^{90} \mathrm{Sr}$ emission from total ${ }^{137} \mathrm{Cs}$ release. Many researchers have estimated the total atmospheric release of ${ }^{137} \mathrm{Cs}$ derived from the FDNPP accident because of one of major emission radionuclides and its long physical and environmental half-lives, which has been summarized in several reviews $[1,2,28]$. Aoyama et al. [29] concluded that the most reliable value of the total atmospheric ${ }^{137} \mathrm{Cs}$ release is $15-20 \mathrm{PBq}$. The total atmospheric ${ }^{90} \mathrm{Sr}$ emission is calculated to be $2.7-3.6 \mathrm{TBq}$ from the median of the ${ }^{90} \mathrm{Sr} /{ }^{137} \mathrm{Cs}$ activity ratios and the total atmospheric ${ }^{137} \mathrm{Cs}$ release, which corresponds to $0.00052-0.00069 \%$ of the total core inventory $\left(5.22 \times 10^{2} \mathrm{PBq}\right)$. This estimated total atmospheric emission of ${ }^{90} \mathrm{Sr}$ is more than one order of magnitude lower than the previous estimate (139TBq) [1]. 
Citation: Hirose K (2017) Sr-90 Deposition Observed in Central and Northeast Honshu Island, Japan, after the Fukushima Dai-ichi Nuclear Power Plant Accident. Int J Earth Environ Sci 2: 134. doi: https://doi.org/10.15344/2456-351X/2017/134

Page 4 of 5

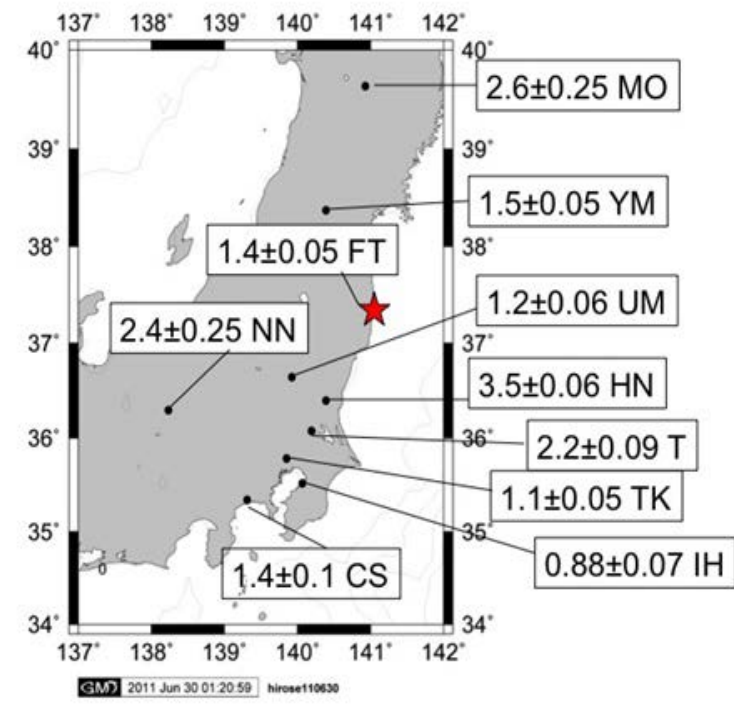

Figure 3: Spatial distribution of the ${ }^{90} \mathrm{Sr} /{ }^{137} \mathrm{Cs}$ activity ratios in deposition samples collected in March 2011. (Unit: $\times 10^{-4}$ )

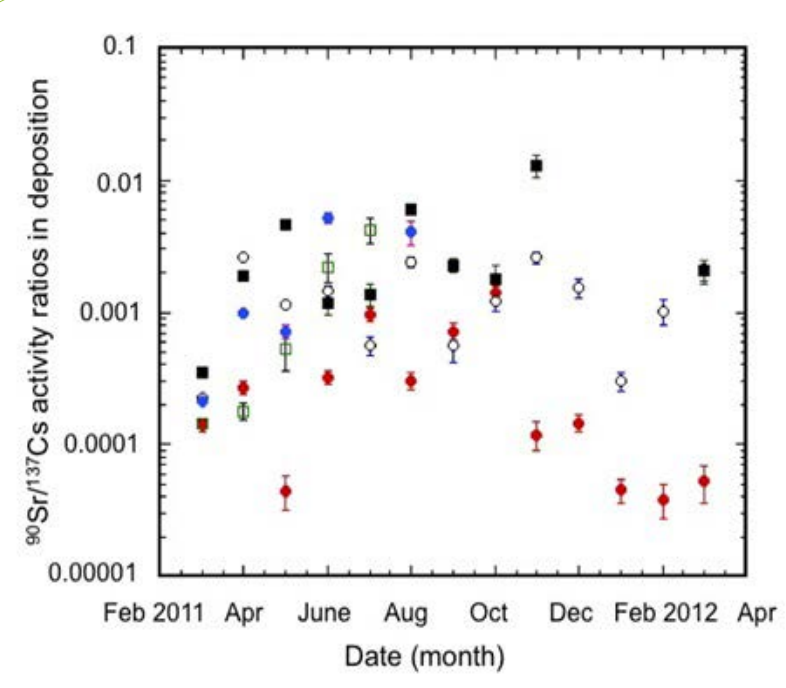

Figure 4: Temporal variations of the ${ }^{90} \mathrm{Sr} /{ }^{137} \mathrm{Cs}$ activity ratios in deposition samples during the period from March 2011 to March 2012. Closed red circle: Futaba, closed black square: Hitachinaka, open black circle: Tsukuba, open green square: Yamagata, closed blue circle: Utsunomiya

The temporal variations of the ${ }^{90} \mathrm{Sr} /{ }^{137} \mathrm{Cs}$ activity ratios in deposition samples collected at Futaba, Hitachinaka, Tsukuba, Utsunomiya and Yamagata are shown in Figure 4. The ${ }^{90} \mathrm{Sr} /{ }^{137} \mathrm{Cs}$ ratios at Futaba near the FDNPP showed around $2 \times 10^{-4}$, although relatively high and low ratios occurred on August - October 2011 and on January - March 2012, respectively. The ${ }^{90} \mathrm{Sr} /{ }^{137} \mathrm{Cs}$ ratios at Hitachinaka, Tsukuba and Utsunomiya, corresponding to the Kanto area, increased from April to June 2011 and have exhibited high values of $0.00055-0.013$ after April 2011, although its large temporal and spatial variations were observed. The ${ }^{90} \mathrm{Sr} /{ }^{137} \mathrm{Cs}$ ratios at Yamagata northwest of the FDNPP increased after May 2011. These findings suggest that atmospheric emission processes and dispersion behaviors of ${ }^{90} \mathrm{Sr}$ and ${ }^{137} \mathrm{Cs}$ after April 2011differed from the initial release in March 2011. To explain long-term atmospheric effects of the FDNPP-derived radionuclides, resuspension hypothesis that ${ }^{90} \mathrm{Sr}$ and ${ }^{137} \mathrm{Cs}$ in deposition were supported by local suspension of surface soil particles has been proposed [6,30,31]. However, it is difficult to explain long-term variations of the ${ }^{90} \mathrm{Sr} /{ }^{137} \mathrm{Cs}$ ratios in the deposition by this hypothesis because ${ }^{90} \mathrm{Sr}$ and ${ }^{137} \mathrm{Cs}$ in local soil are too low to support their deposition levels [6]. One of other possible processes is atmospheric emission from highly contaminated area including the FDNPP [7]. The relatively high ${ }^{90} \mathrm{Sr}$ concentrations (up to $1 \mathrm{kBq} \mathrm{kg}^{-1}$ ) were observed in surface soil near the FDNPP collected in the period of December 2011 to July 2012, which correspond to higher ${ }^{90} \mathrm{Sr} /{ }^{137} \mathrm{Cs}$ ratios in the major emission [32]. The post accident sporadic release of radionuclides may be contained more enriched ${ }^{90} \mathrm{Sr}$ than in the initial release because TEPCO implemented selective removal of radiocesium in contaminated water at the first stage. In fact, one major sporadic release of radionuclides as a late emission was observed on August 19, 2013, in which higher ${ }^{90} \mathrm{Sr}$ contamination and higher ${ }^{90} \mathrm{Sr} /{ }^{137} \mathrm{Cs}$ ratio (0.04) in a soil sample corresponding to the simulated plume line [33]. However, factors controlling the complicated temporal variations of the ${ }^{90} \mathrm{Sr} /{ }^{137} \mathrm{Cs}$ activity ratios are still unknown as mentioned by Igarashi et al. [8].

\section{Conclusion}

We summarized monitoring results of radiostrontium after the Fukushima Daiichi Nuclear Power Plant accident. Radiostrontium ${ }^{89} \mathrm{Sr}$ and $\left.{ }^{90} \mathrm{Sr}\right)$ was released in the atmosphere due to the FDNPP accident. Since the maximum deposition on March 2011 just after the FDNPP accident, the monthly ${ }^{90} \mathrm{Sr}$ deposition in the sites decreased with time. The late effects of ${ }^{90} \mathrm{Sr}$ in deposition continued more than one year, although the area affected by ${ }^{90} \mathrm{Sr}$ is limited comparing with ${ }^{137} \mathrm{Cs}$. For the initial emission in March 2011 , the ${ }^{90} \mathrm{Sr} /{ }^{137} \mathrm{Cs}$ activity ratios in deposition samples with a median of $1.8 \times 10^{-4}$ were approximately constant. The total atmospheric emission of ${ }^{90} \mathrm{Sr}$ is estimated to be $2.7-3.6 \mathrm{TBq}$ from the ${ }^{90} \mathrm{Sr} /{ }^{137} \mathrm{Cs}$ ratio and the total release amount of ${ }^{137} \mathrm{Cs}$. The ${ }^{90} \mathrm{Sr} /{ }^{137} \mathrm{Cs}$ activity ratios in deposition samples showed large spatial and temporal variability, which reflects complicated atmospheric behaviors of ${ }^{90} \mathrm{Sr}$ and ${ }^{137} \mathrm{Cs}$ including postaccident sporadic releases from the FDNPP site.

\section{Competing Interests}

The author declares no financial competing interest.

\section{Acknowledgement}

Author would appreciate staff members of the Prefectural Governments in Japan, JCAC and MRI for great efforts on measurements of radioactivity in deposition samples.

\section{References}

1. Povinec PP, Hirose K, Aoyama M (2013) Fukushima Accident: Radioactivity Impact on the Environment, Elsevier, New York.

2. Hirose K (2016) Fukushima Daiichi nuclear plant accident: atmospheric and oceanic impacts over the five years. J Environ Radioact 157: 1-18.

3. Amano H, Akiyama M, Chunlei B, Kawamura T, Kishimoto T, et al. (2012) Radiation measurements in the Chiba Metropolitan area and radiological aspects of fallout from the Fukushima Daiichi Nuclear Power Plants accident. J Environ Radioact 111: 42-52.

4. Doi T, Masumoto K, Toyoda A, Tanaka A, Shibata Y, et al. (2013) Anthropogenic radionuclides in the atmosphere observed at Tsukuba: Characteristics of the radionuclides derived from Fukushima. J Environ Radioact 122: 55-62. 
Citation: Hirose K (2017) Sr-90 Deposition Observed in Central and Northeast Honshu Island, Japan, after the Fukushima Dai-ichi Nuclear Power Plant Accident. Int J Earth Environ Sci 2: 134. doi: https://doi.org/10.15344/2456-351X/2017/134

Page 5 of 5

5. Hirose K (2012) 2011 Fukushima Daiichi nuclear power plant accident summary of regional radioactivity deposition monitoring results. J Environ Radioact 111: 13-17.

6. Hirose K (2013) Temporal variation of monthly ${ }^{137} \mathrm{Cs}$ deposition observed in Japan: effects of the Fukushima Daiichi nuclear power plant accident. App Radiat Isot 66: 1675-1678.

7. Hirose K (2015) Two-years trend of monthly ${ }^{137} \mathrm{Cs}$ deposition observed in Kanto and south Tohoku areas, Japan: effects of the Fukushima Dai-ich nuclear power plant accident. J Radioanal Nucl Chem 303: 1327-1329.

8. Igarashi Y, Kajino M, Zaizen Y, Adachi K, Mikami M (2015) Atmospheric radioactivity over Tsukuba, Japan: a summary of three years of observations after the FDNPP accident. Prog Earth Planet Sci 2: 44.

9. Schwantes JM, Orton CR, Clark RA (2012) Analysis of a nuclear accident: fission and activation product releases from the Fukushima Daiichi nuclear facility as remote indicators of source identification, extent of release, and state of damaged spent nuclear fuel. Environ Sci Technol 46: 8621-8627.

10. Katsuragi $Y(1983)$ A study of ${ }^{90} \mathrm{Sr}$ fallout in Japan. Pap Meteor Geophys 33: $277-291$

11. Hirose K, Aoyama M, Katsuragi K, Sugimura $Y$ (1987) Annual deposition of Sr-90, Cs-137 and Pu-239,240 from the 1961-1980 nuclear explosions: A simple model. J Meteor Soc Jpn 65: 259-277.

12. Hirose K, Igarashi $Y$, Aoyama M (2008) Analysis of 50 years records of atmospheric deposition of long-lived radionuclides in Japan. Appl Radiat Isot 66: 1675-1678.

13. Igarashi Y, Aoyama M, Hirose K, Povinec P,Yabuki S (2005) What anthropogenic radionuclides $\left({ }^{90} \mathrm{Sr}\right.$ and $\left.{ }^{137} \mathrm{Cs}\right)$ in atmospheric deposition, surface soils and aeolian dusts suggest for dust transport over Japan. Water Air Soil Poll Focus 5: 51-69.

14. Povinec PP, Hirose K, Aoyama M (2012) Radiostrotium in the western North Pacific: characteristics, behavior and the Fukushima impact. Environ Sci Technol 46: 10356-10363.

15. Aarkrog A, Dahlgaard H, Nielsen SP, Trapeznikov AV, Molchanova IV, et al. (1997) Radioactive inventories from the Kyshtym and Karachay accidents: estimates based on soil samples collected in the South Urals (1990-1995). Sci Total Environ 201: 137-154.

16. Lee $\mathrm{MH}$, Lee CW (2000) Association of fallout-derived ${ }^{137} \mathrm{Cs}$, ${ }^{90} \mathrm{Sr}$ and ${ }^{239,240} \mathrm{Pu}$ with natural organic substances in soil. Health Phys 79: 253-262.

17. Aoyama M, Hirose $K$, Sugimura $Y$ (1991) The temporal variation of stratospheric fallout derived from the Chernobyl accident. J Environ Radioact 13: 103-115.

18. Igarashi $\mathrm{Y}$, Inomata $\mathrm{Y}$, Aoyama M, Hirose $\mathrm{K}$, Takahashi H, et al. (2009) Possible change in Asian dust source suggested by atmospheric anthropogenic radionuclides during the 2000s. Atmos Environ $43: 2971$ 2980.

19. Igarashi $Y$, Fujiwara $H$, Jugder $D$ (2011) Change of the Asian dust source region deduced from the composition of anthropogenic radionuclides in surface soil in Mongolia. Atmos Chem Phys 11: 7069-7080.

20. NRA (Nuclear Regulation Authority) (2016) Environmental radioactivity database.

21. JCAC (2003) Radioactivity measurement series 2: radioanalytical method of radiostrontium.

22. Otsuji-Hatori M, Igarashi Y, Hirose K (1996) Preparation of a reference fallout material for activity measurements. J Environ Radioact 31: 143-156.

23. Igarashi Y, Aoyama M, Hirose K, Miyao T, Nemoto K, et al. (2003) Resuspension: decadal monitoring time series of the anthropogenic radioactivity deposition in Japan. J Rad Res 44: 319-328.

24. Morino Y, Ohara T, Nishizawa M (2011) Atmospheric behavior, deposition, and budget of radioactive materials from the Fukushima Daiichinuclea power plant in March 2011. Geophys Res Lett 38: 1944-8007.

25. Kavasi N, Sahoo SK, Sorimachi A Tokonami S, Aono T, et al. (2014) Measurement of ${ }^{90} \mathrm{Sr}$ in soil samples affected by the Fukushima Daiich Nuclear Power Plant accident. J Radioanal Nucl Chem 303: 2566-2570.

26. NRA (Nuclear Regulation Authority) (2012) Results of the Radiation Monitoring of Soil in Fukushima Prefecture.
27. Sahoo SK, Kavasi N, Sorimachi A, Arae H, Tokonami S, et al. (2016) Strontium-90 activity concentration in soil samples from the exclusion zone of the Fukushima daiichi nuclear power plant. Sci Rep 6: 23925.

28. Thakur P, Ballard S, Nelson R (2013)An overview of Fukushima radionuclide measured in the northern hemisphere. Sci Total Environ 458-460: 577-613.

29. Aoyama M, Kajino M, Tanaka TY, Sekiyama TT, Tsumune D, et al. (2016) ${ }^{134} \mathrm{Cs}$ and ${ }^{137} \mathrm{Cs}$ in the North Pacific Ocean derived from the March 2011 TEPCO Fukushima Dai-ichi Nuclear Power Plant accident, Japan. Part Two: estimation of ${ }^{134} \mathrm{Cs}$ and ${ }^{137} \mathrm{Cs}$ inventories in the North Pacific Ocean. J Oceanogr 72: 67-76.

30. Hirose K, Igarashi Y, Aoyama M, Kim CK, Kim CS, et al. (2003) Recent trends of plutonium fallout observed in Japan: plutonium as a proxy for desertification. J Environ Monitor 5: 1-7.

31. Hirose K, Igarashi Y, Aoyama M, Inomata $Y$ (2010) Depositional behaviors of plutonium and thorium at Tsukuba and Mt. Haruna in Japan indicate the sources of atmospheric dust. J Environ Radioact 101: 106-112.

32. Steinhauser G, Schauer V, Shozugawa K (2013) Concentrations of strontium-90 at selected hot spots in Japan. PLoS ONE 8: e57760.

33. Steinhauser G, Niisoe T, Harada KH, Shozugawa K, Schneider S (2015) Post-accident sporadic releases of airborne radionuclides from the Fukushima Daiichi Nuclear Power Plant Site. Environ Sci Technol 49: 14028-14035. 